\title{
Water Levels in Selected Wells and Directions of Ground-Water Movement Near Fort Hall, Fort Hall Indian Reservation, Southeastern Idaho
}

By D.J. Parliman and H.W. Young

U.S. Geological Survey

Water-Resources Investigations Report 92-4014

Prepared in cooperation with the

SHOSHONE-BANNOCK TRIBES,

FORT HALL INDIAN RESERVATION 


\section{U.S. DEPARTMENT OF THE INTERIOR \\ BRUCE BABBITT, Secretary}

\section{U.S. GEOLOGICAL SURVEY}

Dallas L. Peck, Director

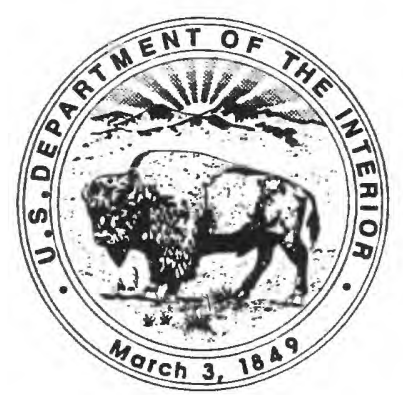

For additional information write to:

District Chief U.S. Geological Survey 230 Collins Road Boise, ID 83702
Copies of this report can be purchased from:

U.S. Geological Survey Books and Open-File Reports Section Federal Center, Box 25425

Denver, CO 80225 


\title{
CONTENTS
}

\author{
Abstract 1 \\ Introduction 1 \\ Purpose and scope 1 \\ Acknowledgments 4 \\ Description of the study area 4 \\ Geology 4 \\ Hydrology 4 \\ Water levels in selected wells, 1985-90 4 \\ Directions of ground-water movement, April 19905 \\ Summary 8 \\ References cited 8
}

\section{ILLUSTRATIONS}

1-2. Maps showing:

1. Location of study area, Gibson Terrace, and surrounding areas 2

2. Location and identification of wells on or near the Gibson Terrace in which water levels were measured in March or April 19903

3-5. Hydrographs showing:

3. Water levels in wells 12, 13, and 14, September 1985 to March 19905

4. Water levels in wells 36,37 , and 38, October 1985 to April 19905

5. Water levels in wells 49 and 72, April 1985 to March 19905

6. Map showing water-level contours and general directions of ground-water movement in deeper unconsolidated deposits, April 19906

7. Map showing water-level contours and general directions of ground-water movement in basalt, April 19907

\section{TABLE}

1. Well-construction, water-use, and water-level data, March and April 19909 


\begin{tabular}{rcl}
\hline \multicolumn{1}{c}{ Multiply } & By & \multicolumn{1}{c}{ To obtain } \\
\hline acre & 4,047 & square meter \\
foot $(\mathrm{ft})$ & 0.3048 & meter \\
inch (in.) & 25.4 & millimeter \\
mile (mi) & 1.609 & kilometer \\
square mile (mi $\left.{ }^{2}\right)$ & 2.590 & square kilometer \\
\hline
\end{tabular}

Sea level: In this report, "sea level" refers to the National Geodetic Vertical Datum of 1929-a geodetic datum derived from a general adjustment of the first-order level nets of the United States and Canada, formerly called Sea Level Datum of 1929.

\section{WELL-NUMBERING SYSTEM}

The well-numbering system used by the U.S. Geological Survey in Idaho indicates the location of wells within the official rectangular subdivision of public land, with reference to the Boise base line and Meridian. The first two segments of the number designate the township (north or south) and range (east or west). The third segment gives the section number; three letters, which indicate the $1 / 4$ section (160-acre tract), $1 / 4^{-1 / 4}$ section (40-acre tract), $1 / 4^{-1 / 4^{-}}-1 / 4$ section (10-acre tract); and the serial number of the well within the tract. Some well locations also include a $1 / 4^{-1 / 4^{-1}}-4^{-1 / 4}$ section $\left(21 / 2^{-a c r e}\right.$ tract) letter within the section number.

Quarter sections are designated by the letters A, B, C, and D in counterclockwise order from the northeast quarter of each section. Forty-acre, 10 -acre, and $2 \frac{1}{2}$-acre tracts within each quarter section are lettered in the same manner. For example, well $4 \mathrm{~S}-34 \mathrm{E}-26 \mathrm{DAD} 1$ is in the $\mathrm{SE}^{1 / 4} \mathrm{NE}^{1 / 4} \mathrm{SE}^{1 / 4} \mathrm{sec}$. 26, T. $4 \mathrm{~S}$., $\mathrm{R}$. $34 \mathrm{E}$., and was the first well inventoried in that tract.

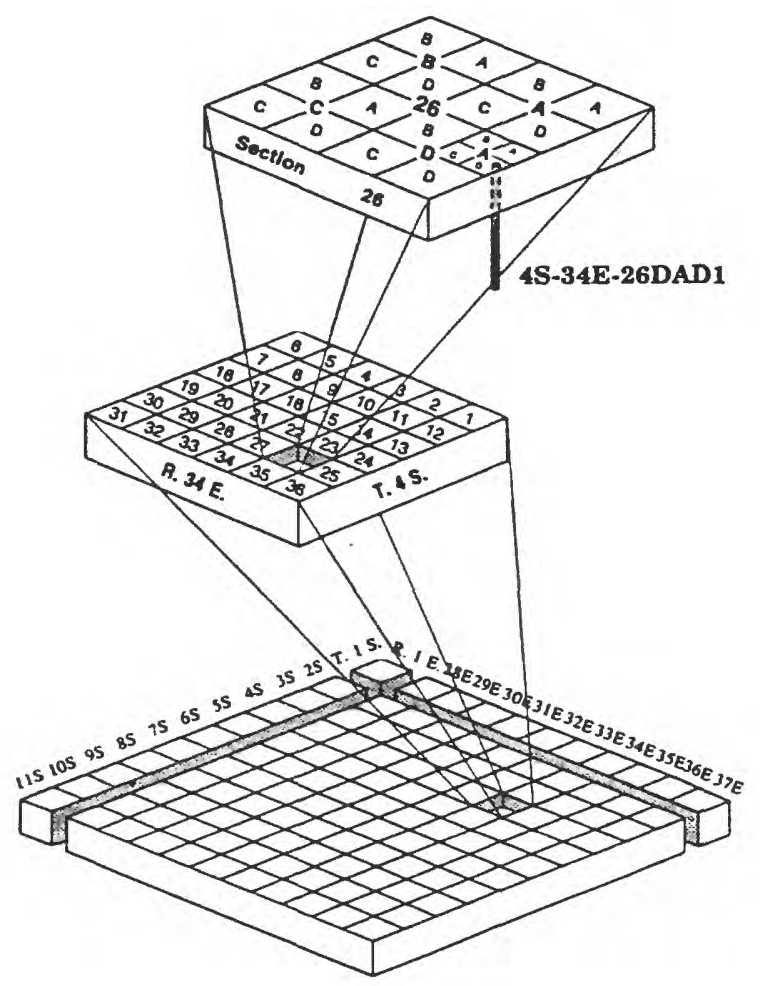




\title{
Water Levels in Selected Wells and Directions of Ground-Water Movement Near Fort Hall, Fort Hall Indian Reservation, Southeastern Idaho
}

\author{
By D.J. Parliman and H.W. Young
}

\section{ABSTRACT}

In April 1990, water levels were measured in 81 wells near Fort Hall to determine directions of ground-water movement in areas where dissolved nitrate-nitrogen concentrations were determined to be consistently high.

Principal rock units are unconsolidated deposits and basalt. Basalt underlies the entire study area. Recharge is primarily from underflow from adjacent areas, precipitation, and locally from applied irrigation water and canal leakage. Principal water-yielding zones are gravel and sand lenses in the unconsolidated deposits and cinder or rubble in the bassalt. The regional ground-water system is in basalt.

Ground water in unconsolidated deposits can be under unconfined (water-table) or confined conditions. Water levels in wells completed in near-surface unconsolidated deposits probably represent unconfined conditions. Water levels in wells completed in deeper unconsolidated deposits (more than approximately 50 feet below land surface) and basalt probably represent a mixture of unconfined and confined conditions. Most domestic wells are completed in deeper unconsolidated deposits and most irrigation wells are completed in basalt.

Hydraulic heads in water-yielding zones in basalt are higher than hydraulic heads in unconsolidated deposits. Water levels generally are lowest in May and highest in October. Hydrographs for all wells show an overall decline in water levels from 1985 to 1990 .

In unconsolidated deposits, the water-level gradient from the Fort Hall Main Canal to the western edge of the Gibson Terrace is about 2 feet per mile. The general directions of ground-water movement are westward and southwestward toward the Fort Hall Bottoms. In basalt, the water-level gradient is about 1 foot per mile, and directions of ground-water movement are southwestward toward the Fort Hall Bottoms and northwestward toward Ferry Butte.

\section{INTRODUCTION}

Historically, ground-water level data were sparse for areas near Fort Hall on the Fort Hall Indian Reservation (fig. 1). Two ground-water quality studies were completed in this area by the U.S. Geological Survey (USGS), in cooperation with the Shoshone-Bannock Tribes, during 1988 and 1989 (Parliman and Young, 1988, 1989). Dissolved nitrite plus nitrate as nitrogen concentrations (nitrate-nitrogen) were consistently high in water samples from wells located between Fort Hall and Ferry Butte, on and near the Gibson Terrace (first described in a report by Mansfield, 1920, p. 16), but water-level data were needed to help determine directions of ground-water movement. Information also was needed on principal water-yielding zones, seasonal and long-term variability of water levels in wells completed in different water-yielding zones, and water levels prior to large groundwater withdrawals during the irrigation season.

In March 1990, the USGS, in cooperation with the Shoshone-Bannock Tribes, began a study to determine directions of ground-water movement on and near the Gibson Terrace where dissolved nitrate-nitrogen concentrations were determined to be consistently high.

\section{Purpose and Scope}

The primary purposes of this report are to (1) present measurements of water levels in wells on and near the Gibson Terrace, (2) define waterlevel contours, and (3) define directions of ground-water movement.

The scope of the study included (1) compilation of water-level and well-construction information for areas near Fort Hall, including the Gibson Terrace; (2) measurement of water levels in 81 wells between April 9 and 18, 1990; and (3) construction of water-level contour maps from which directions of ground-water movement could be determined. Water levels were measured when canals and ditches were dry and prior to the beginning of the irrigation season. Water-level data from seven additional wells, part of a Fort Hall Indian Reservation water-level monitoring network, also were compiled for use in this study. Water levels in these monitoring wells were measured in March 1990. Locations of the 88 wells are shown in figure 2. Well-construction, wateruse, and selected water-level data for each well are shown in table 1 (back of report). 


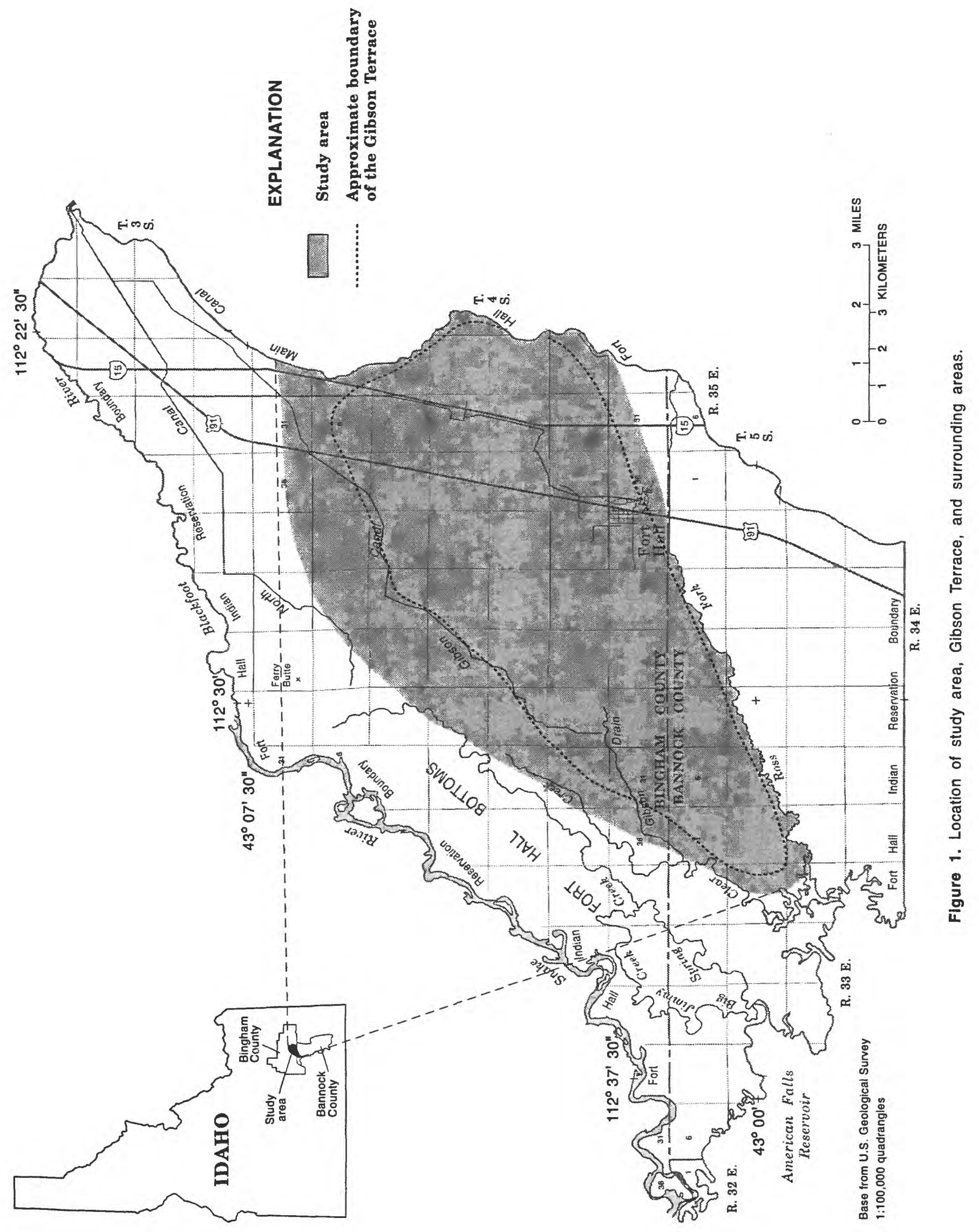




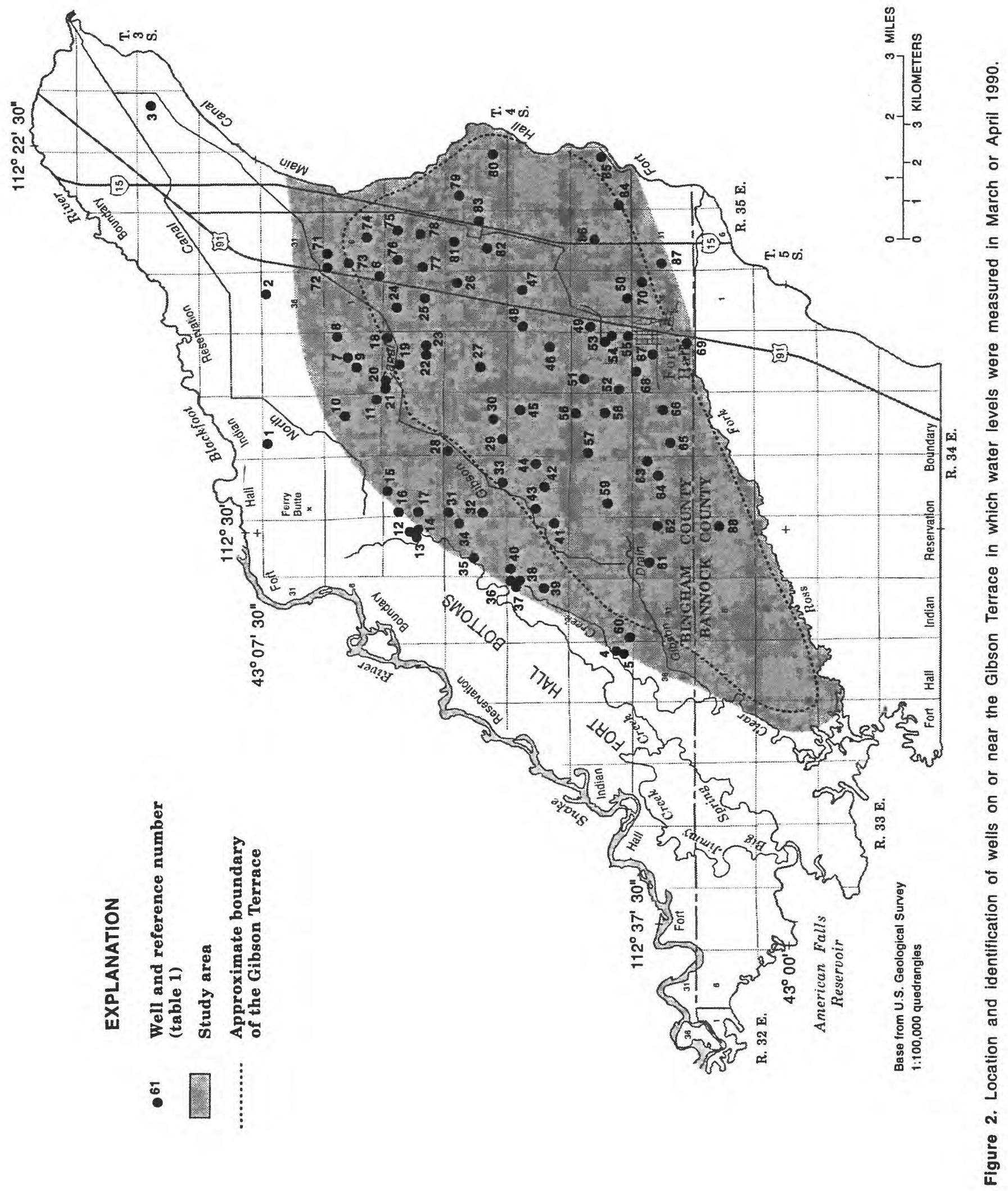




\section{Acknowledgments}

Well-construction information necessary for the completion of this project was furnished by private well owners, public and private business personnel, and State and Federal agency personnel in Idaho. Personnel with the Shoshone-Bannock Tribes; U.S. Department of the Interior, Bureau of Indian Affairs at Fort Hall; and Portland Area Indian Health Service in Seattle, Wash., also provided information on historical land uses, water uses, and ground-water quality that was important for understanding the ground-water system near Fort Hall.

\section{DESCRIPTION OF THE STUDY AREA}

The study area comprises about $45 \mathrm{mi}^{2}$ near Fort Hall and includes lowlands from Ross Fork northward to Ferry Butte, westward to the Fort Hall Bottoms, and eastward to the Fort Hall Main Canal. Land-surface altitude ranges from about 4,400 to $4,500 \mathrm{ft}$ above sea level, and the land slopes generally southwestward.

The climate is semiarid, characterized by cold, wet winters and hot, dry summers. Mean annual precipitation is about 11 in. Precipitation is greatest during winter and spring and least during late summer.

Economy of the study area is strongly influenced by irrigated agriculture. Major crops include potatoes, grains, and alfalfa. Crops are irrigated from about mid-April through September. Irrigation water is provided by canals, ditches, and numerous large-capacity wells. Historically, cropland in the southwestern part of the study area was developed more slowly than in other areas, owing to numerous wetlands. Complex systems of tile drains in some wetland areas divert near-surface water to drain wells; drain water then is pumped to the Gibson Drain.

\section{GEOLOGY}

Principal rock units include recent unconsolidated stream and windblown deposits; older stream, glacial, windblown, lake, and playa deposits; and basalt and associated interbeds of the
Snake River Group of Quaternary age (Mansfield, 1920; Dow, 1978; Parliman, 1987, p. 14).

Unconsolidated gravel, sand, silt, and clay are the predominant deposits and overlie the basalt. Basalt and associated interbeds underlie the entire area. Basalt can be highly fractured or unfractured. Interbeds include uneven thicknesses of volcanic cinders, rubbly basalt, or unconsolidated deposits. Basalt surfaces are undulating; local relief is tens of feet. Altitude of the top of the basalt surface is given in table 1 for wells completed in basalt. Data for wells in T. 4 S., R. 35 E., sec. 7 (wells 75-78, table 1) exemplify the irregularity of the basalt surface.

\section{HYDROLOGY}

Recharge to the ground-water system is primarily from underflow from adjacent areas, precipitation, and locally from applied irrigation water and canal leakage. Precipitation is a major source of recharge from about March until May. Infiltration of applied irrigation water and canal leakage are important sources of recharge from late April until about October.

Principal water-yielding zones are gravel and sand lenses in the overlying unconsolidated deposits and cinder or rubble in the basalt. The regional ground-water system is in basalt.

\section{Water Levels In Selected Wells, 1985-90}

Ground water in unconsolidated deposits can be under unconfined (water-table) or confined (artesian) conditions. Water levels in wells completed in near-surface unconsolidated deposits (less than approximately $50 \mathrm{ft}$ below land surface) probably represent unconfined conditions. Water levels in wells cased to and completed in deeper unconsolidated deposits and basalt probably represent a mixture of unconfined and confined conditions. Most domestic wells in the study area are more than $60 \mathrm{ft}$ deep and are completed in the deeper unconsolidated deposits. Most irrigation wells in the area are more than $200 \mathrm{ft}$ deep and are completed in the basalt.

Changes in water levels in wells completed at different depths are shown in figures 3 and 4 for two well nests (single boreholes containing several 


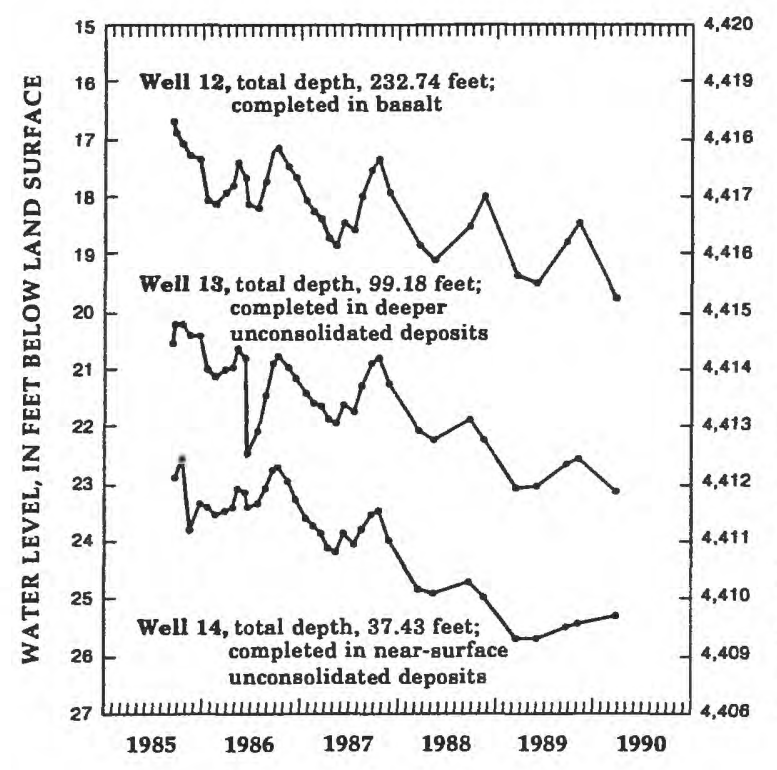

Figure 3. Water levels in wells 12, 13, and 14, September 1985 to March 1990. (See table 1)

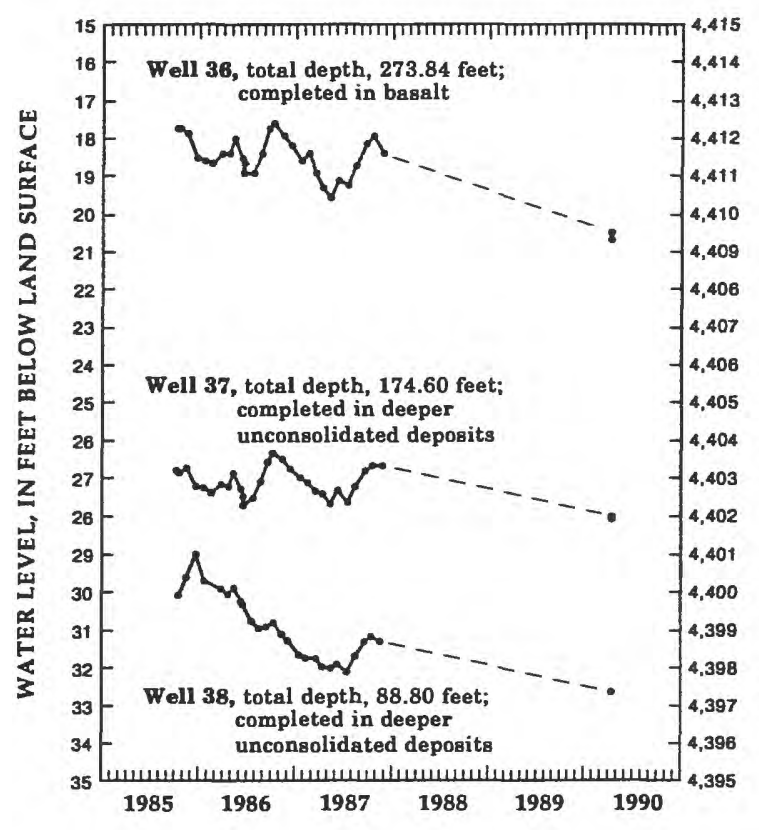

Figure 4. Water levels in wells 36,37 , and 38 , October 1985 to April 1990. (Dashed lines indicate periods for which no data are available; see table 1)

wells completed in discrete water-yielding zones) near the Fort Hall Bottoms (reference numbers 12-14 and $36-38$, table 1). Variability of water levels in deeper unconsolidated deposits near Fort Hall (reference num-

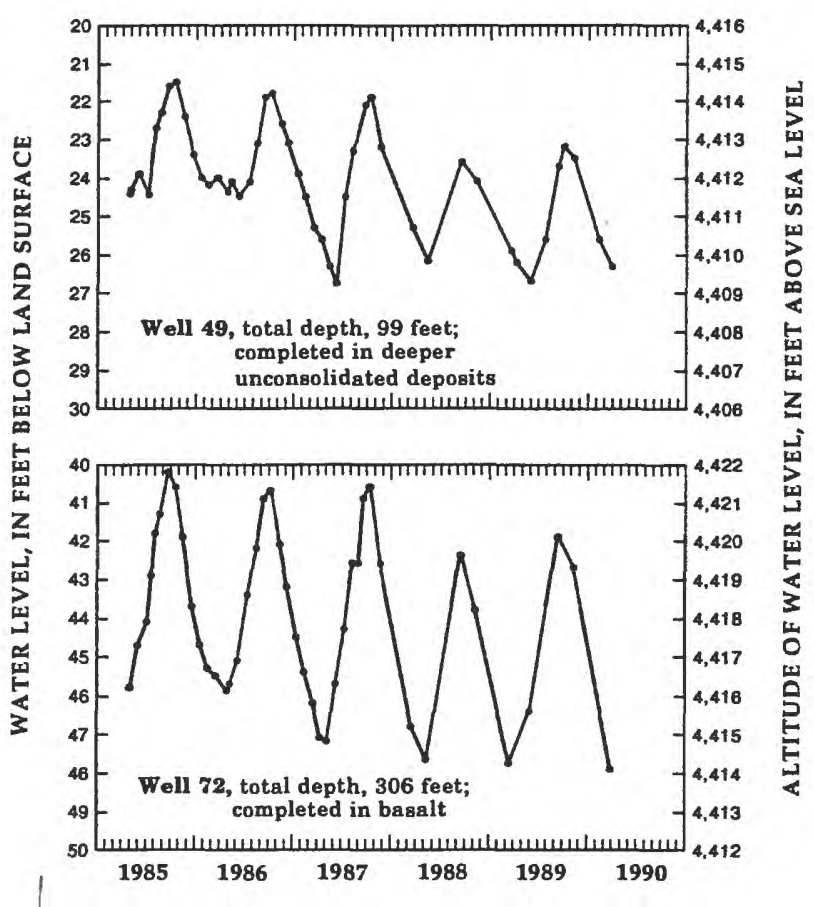

Figure 5. Water levels in wells 49 and 72 , April 1985 to March 1990. (See table 1)

ber 49) and in basalt near Gibson (reference number 72) is shown in figure 5. At each well nest, hydraulic heads in water-yielding zones in the basalt are higher than hydraulic heads in unconsolidated deposits.

Seasonal water-level trends in all hydrographs are similar-water levels typically are lowest in May and highest in October-but patterns and amplitudes of seasonal water-level change differ from zone to zone. Water levels in all water-yielding zones declined from 1985 to 1990.

\section{Directions of Ground-Water Movement, April 1990}

Water-level contours and general directions of ground-water movement in deeper unconsolidated deposits are shown in figure 6. Water-level contours and general directions of ground-water movement in basalt are shown in figure 7. Ground-water movement is in the direction of the decreasing water-level gradient, generally from areas of recharge to areas of discharge. Arrows showing the direction of movement in figures 6 and 7 are drawn perpendicular to contours on the water-level surface. 


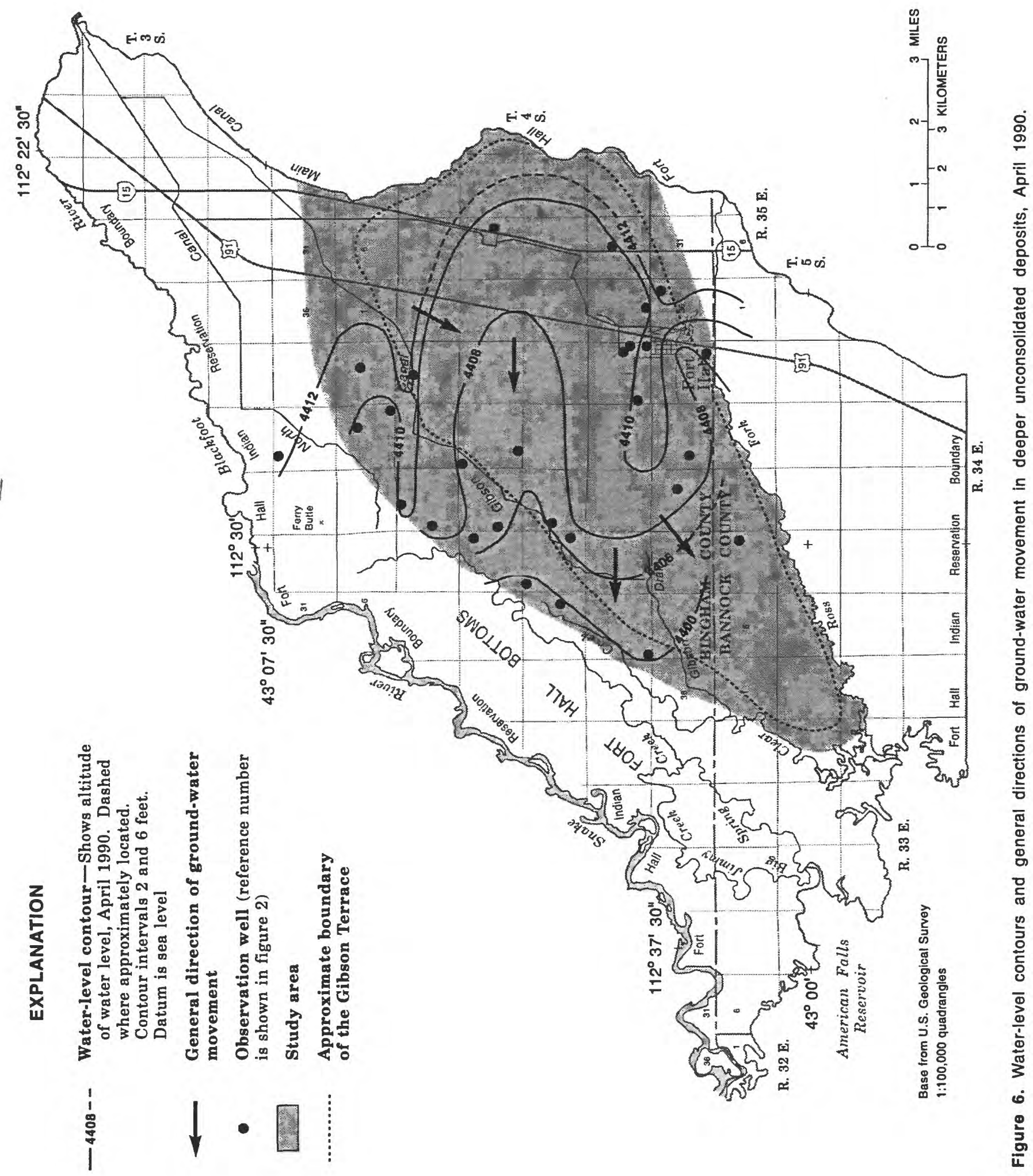




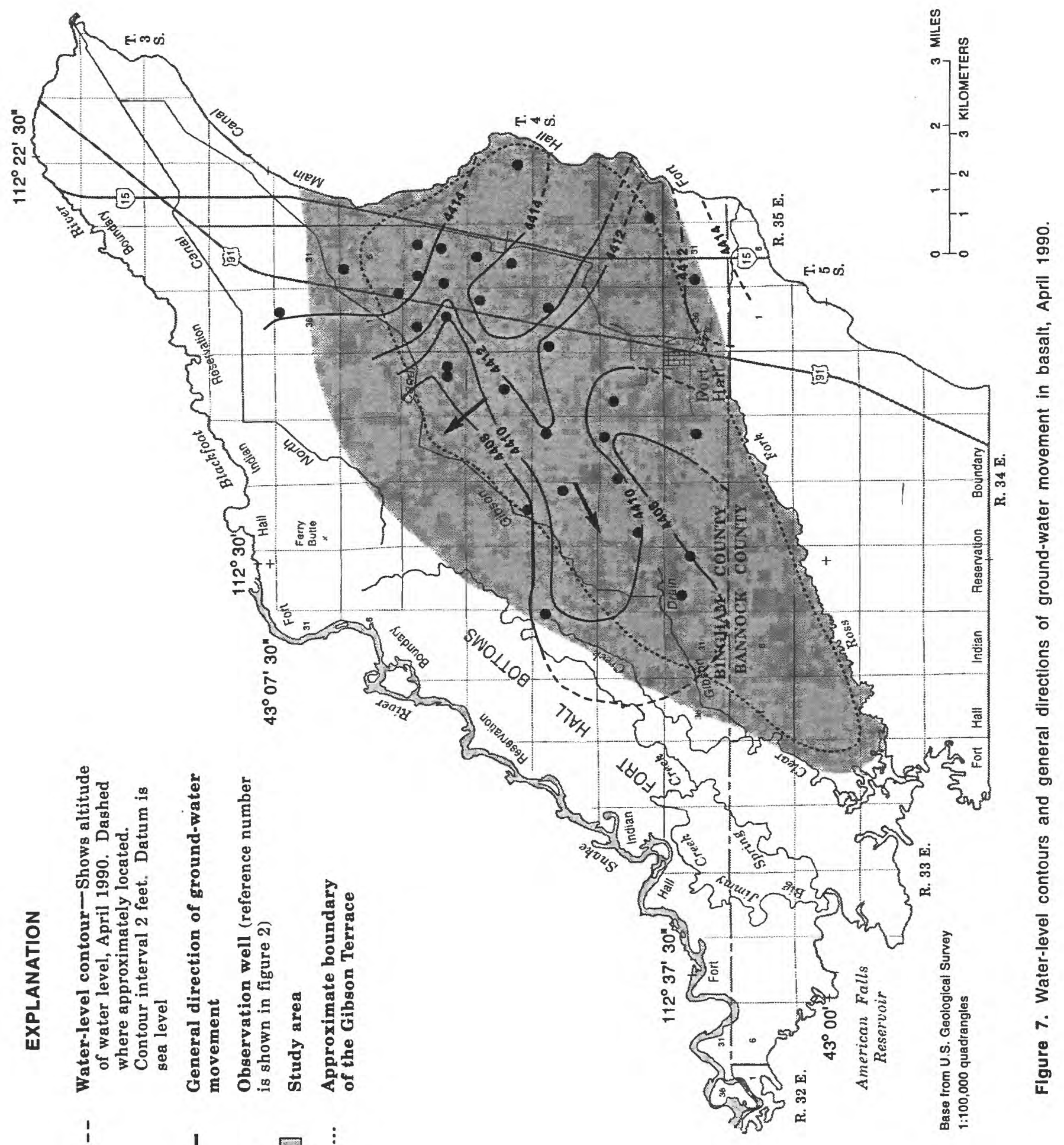


In the deeper unconsolidated deposits, the water-level gradient from the Fort Hall Main Canal to the western edge of the Gibson Terrace is about $2 \mathrm{ft} / \mathrm{mi}$. Gradients are greatest (about $4 \mathrm{ft} / \mathrm{mi}$ ) in areas near Ferry Butte, Fort Hall, and the western edge of the Gibson Terrace and least (less than $1 \mathrm{ft} / \mathrm{mi}$ ) in the central part of the Gibson Terrace. The general directions of ground-water movement are westward and southwestward toward the Fort Hall Bottoms.

In the basalt, the water-level gradient from the Fort Hall Main Canal to the eastern edge of the Gibson Terrace is about $1 \mathrm{ft} / \mathrm{mi}$. Gradients are greatest (more that $2 \mathrm{ft} / \mathrm{mi}$ ) in T. 4 S., R. $34 \mathrm{E}$., secs. $11-15$ and least (less than $0.5 \mathrm{ft} / \mathrm{mi}$ ) in the central part of the Gibson Terrace. General directions of ground-water movement are southwestward toward the Fort Hall Bottoms and northwestward toward Ferry Butte.

\section{SUMMARY}

In April 1990, water levels were measured in 81 wells near Fort Hall to determine directions of ground-water movement in areas where dissolved nitrate-nitrogen concentrations were determined to be consistently high.

Principal rock units in the area are unconsolidated deposits and basalt. Basalt underlies the entire area, and basalt surfaces are undulating.

Recharge to the ground-water system is primarily from underflow, precipitation, and locally from applied irrigation water and canal leakage. Principal water-yielding zones are gravel and sand lenses in the unconsolidated deposits and cinder or rubble in the basalt. The regional ground-water system is in basalt.

Ground water in unconsolidated deposits can be under unconfined or confined conditions. Water levels in wells completed in near-surface unconsolidated deposits probably represent unconfined conditions. Water levels in wells cased to and completed in deeper unconsolidated deposits and basalt probably represent a mixture of unconfined and confined conditions. Most domestic wells are completed in the deeper unconsolidated deposits; most irrigation wells are completed in the basalt.

Hydraulic heads in basalt are higher than hydraulic heads in unconsolidated deposits. Water levels generally are lowest in May and highest in October. Hydrographs of water levels for all wells show an overall decline in water levels from 1985 to 1990 .

In deeper unconsolidated deposits, the waterlevel gradient from the Fort Hall Main Canal to the western edge of the Gibson Terrace is about $2 \mathrm{ft} / \mathrm{mi}$. The general directions of ground-water movement are westward and southwestward toward the Fort Hall Bottoms. In basalt, the water-level gradient is about $1 \mathrm{ft} / \mathrm{mi}$, and directions of ground-water movement are southwestward toward the Fort Hall Bottoms and northwestward toward Ferry Butte.

\section{REFERENCES CITED}

Dow, D.C., 1978, Shoshone-Bannock Tribes-Gibson irrigation wells: Tacoma, Wash., Robinson and Noble, Inc., 25 p.

Mansfield, G.R., 1920, Geography, geology, and mineral resources of the Fort Hall Indian Reservation, Idaho: U.S. Geological Survey Bulletin 713, 152 p.

Parliman, D.J., 1987, Hydrogeology and water quality of areas with persistent ground-water contamination near Blackfoot, Bingham County, Idaho: U.S. Geological Survey Water-Resources Investigations Report 87-4150, 102 p.

Parliman, D.J., and Young, H.W., 1988, Selected waterquality data for the Fort Hall Indian Reservation, southeastern Idaho, July 1988: U.S. Geological Survey Open-File Report 88-496, scale 1:100,000. 1989 , Selected ground-water quality data for the area near Fort Hall, Fort Hall Indian Reservation, southeastern Idaho, June 1989: U.S. Geological Survey Open-File Report 89-594, scale 1:100,000. 


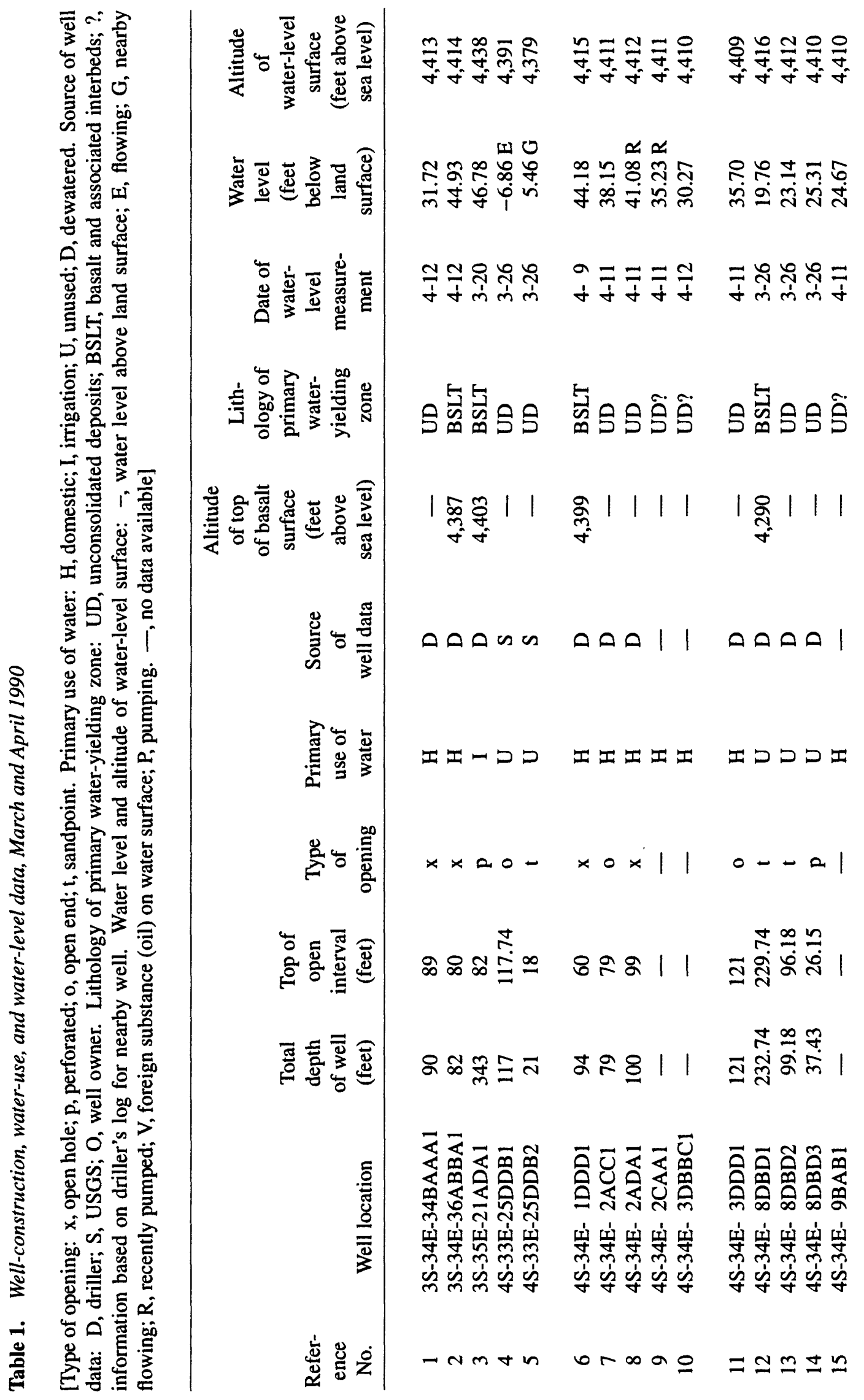




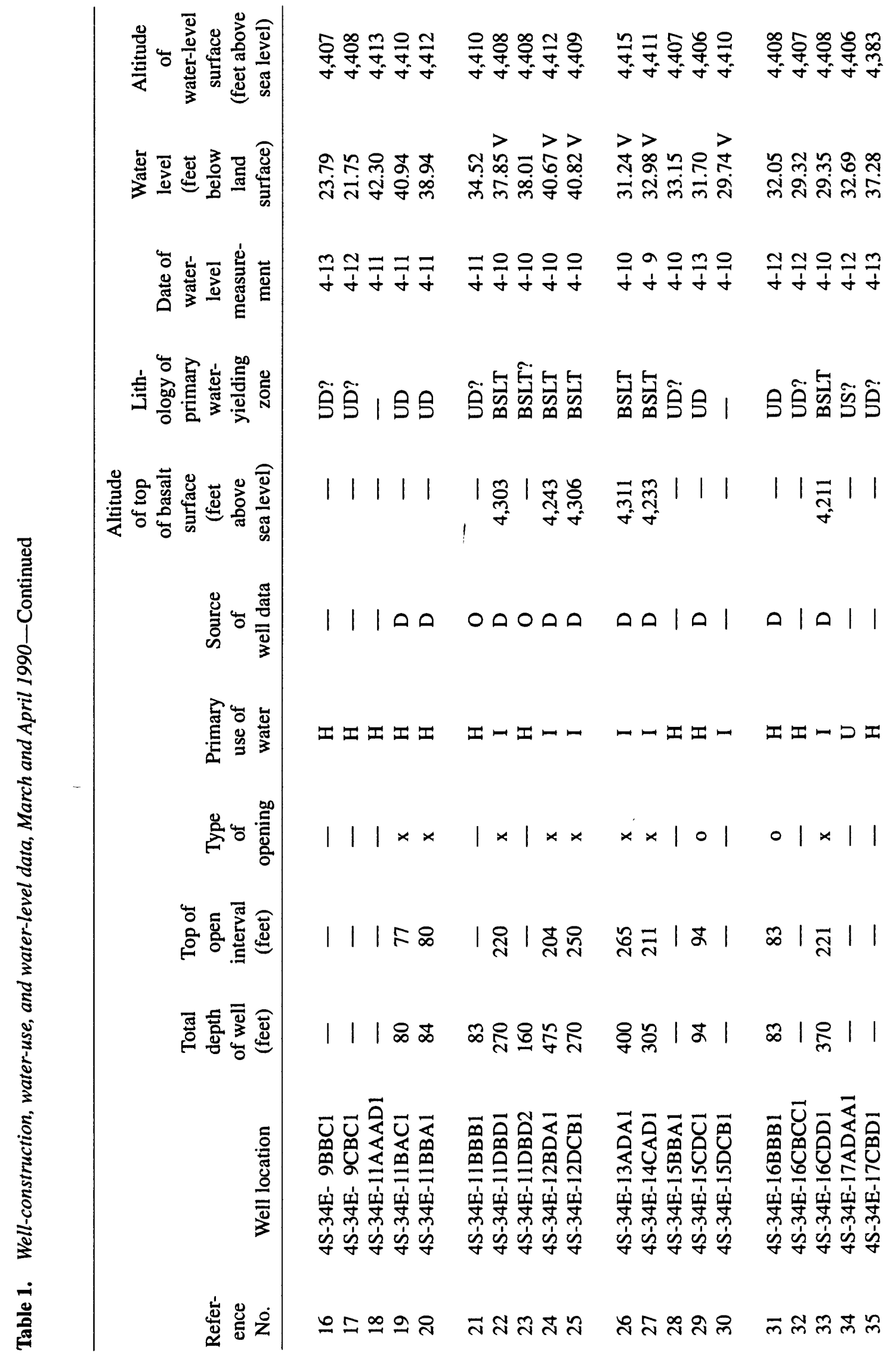




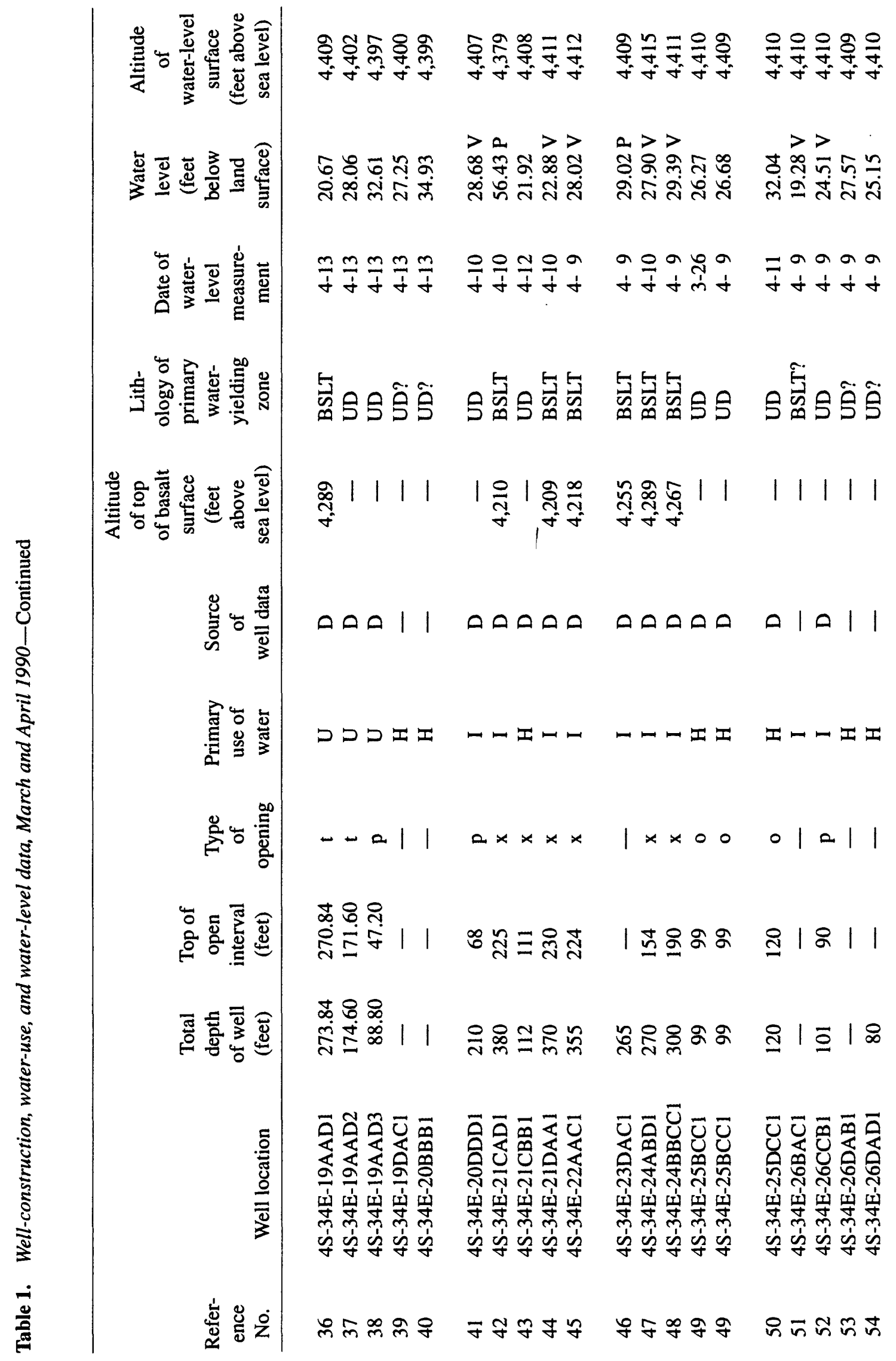




\begin{tabular}{|c|c|c|c|c|}
\hline 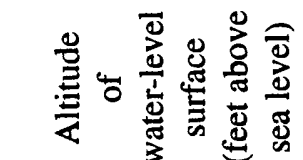 & 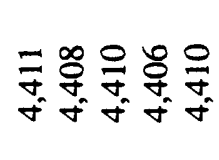 & 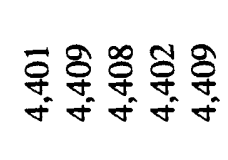 & 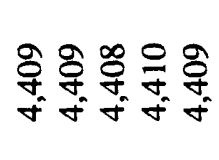 & 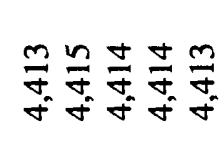 \\
\hline 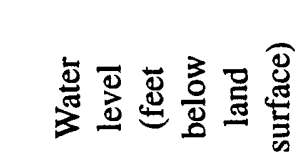 & 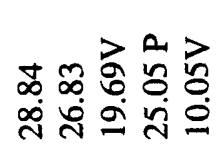 & 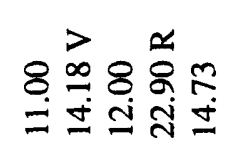 & 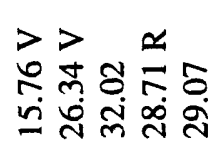 & 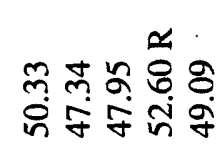 \\
\hline 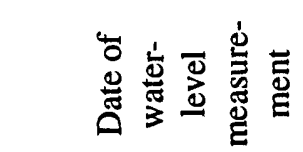 & $\frac{m a}{\dot{b}}+\frac{2}{d} \frac{0}{b}$ & $\frac{m}{4} \frac{9}{4}+\frac{9}{4}+\frac{1}{4}$ & 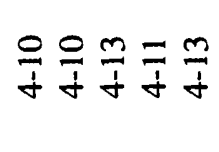 & 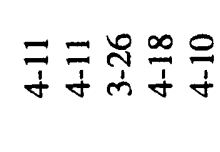 \\
\hline 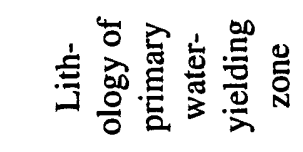 & 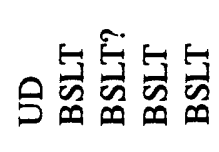 & 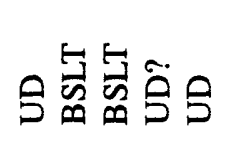 & 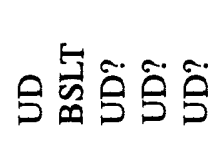 & 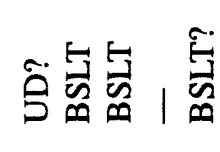 \\
\hline 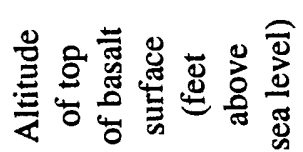 & 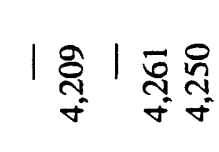 & 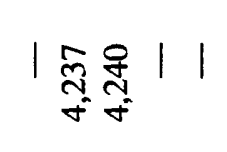 & $|\underset{\substack{\mathbb{f} \\
\underset{\sigma}{\infty}}}{\mid}|$ & 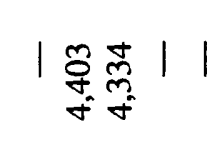 \\
\hline 這 & مص & $000 \mid 0$ & D 111 & $|000|$ \\
\hline 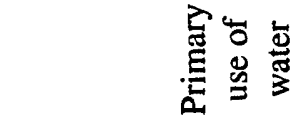 & ロロローの & I & エエエ & エロつェー \\
\hline 崫它咅 & $|x| \times x$ & $x \times x \mid a$ & $a \times 111$ & $|x a| \mid$ \\
\hline 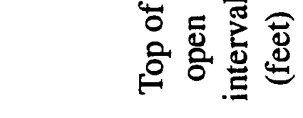 & 1\&1 육 & $\triangleq \infty \infty \mid \tilde{\infty}$ & $\infty \approx 111$ & $|\bar{\Xi} \overline{\mid}|$ \\
\hline 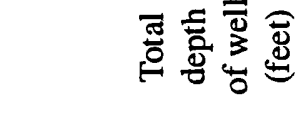 & 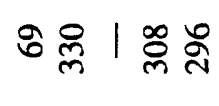 & 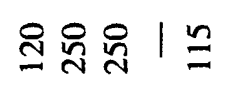 & $\Xi \underset{\infty}{\infty} \mid 18$ & | వర్లి ర్లం | \\
\hline 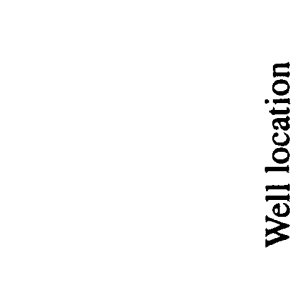 & 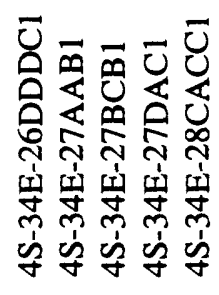 & 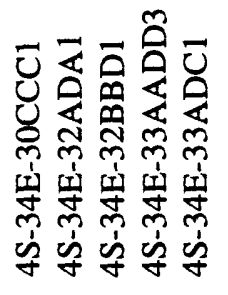 & 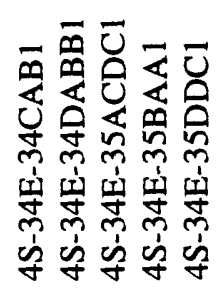 & 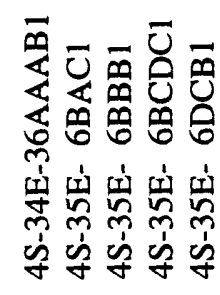 \\
\hline 岕 苞 & $i n$ & 86 రీ 8 & $\therefore 8588$ & 尺 \\
\hline
\end{tabular}




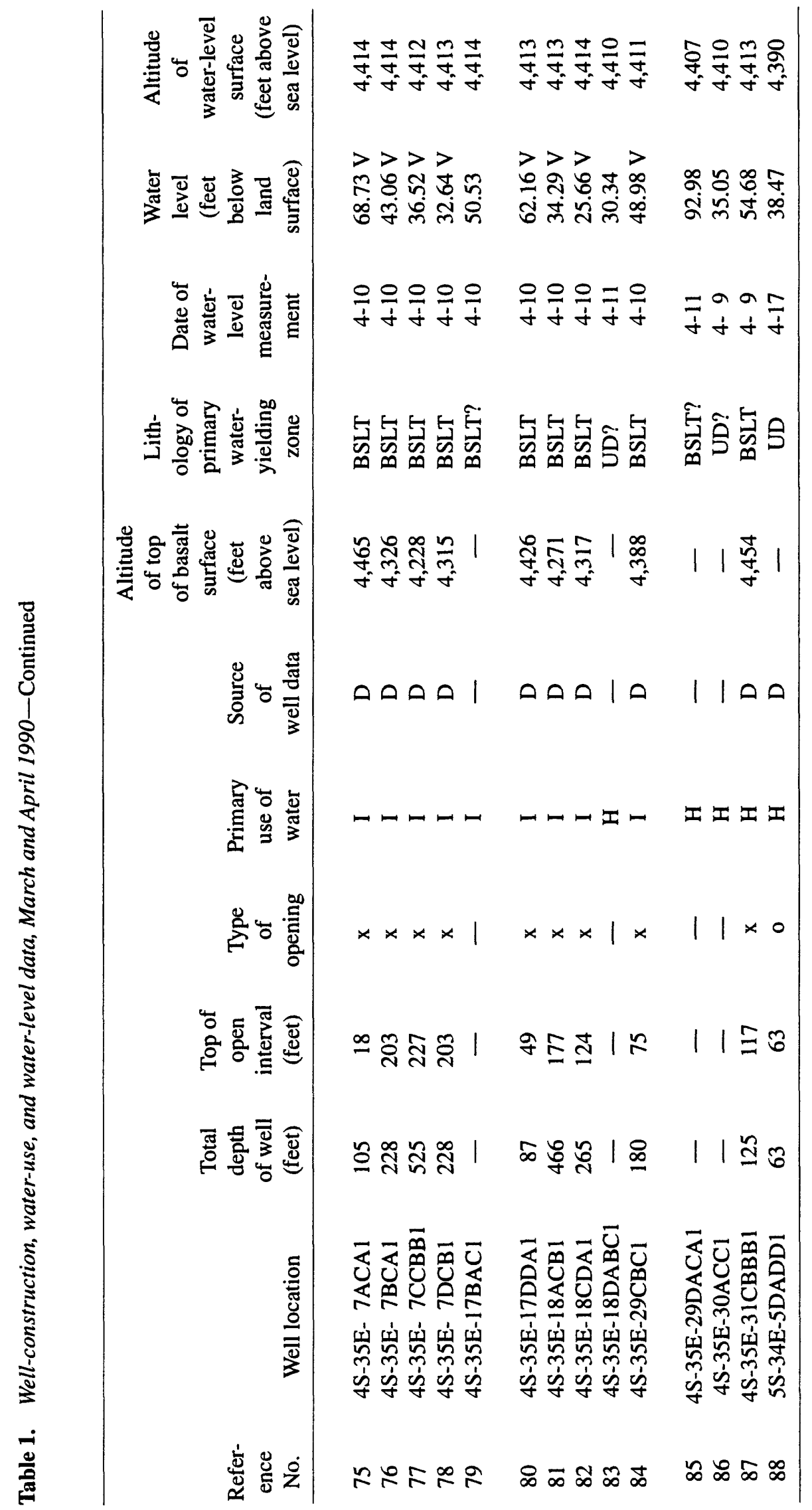

